\title{
Keragaman Serangga Hama pada Tanaman Asparagus (Asparagus officinalis L.) di Sentra Budidaya Tanaman Agroduta Lembang Jawa Barat
}

\author{
Agus Susanto ${ }^{1}$, Yadi Supriyadi ${ }^{1}$, Tohidin ${ }^{1}$ dan Mohammad Iqbal ${ }^{2}$ \\ ${ }^{1}$ Departemen Hama dan Penyakit Tumbuhan, Fakultas Pertanian, Universitas Padjadjaran \\ ${ }^{2}$ Alumni Departemen HPT, Fakultas Pertanian, Universitas Padjadjaran \\ *Alamat korespondensi: asusanto@unpad.ac.id
}

\author{
ABSTRACT \\ Variety of Insect Pest on Asparagus Plant (Asparagus officinalis L.) in Agroduta Plant Cultivation \\ Center Lembang West Java
}

Agroduta Plant Cultivation Center Lembang West Java is facing some constraints in increasing asparagus production; one of them is the presence of plant pest organisms. Asparagus is a subtropical plant rarely cultivated in Indonesia and may have different types of pests. Therefore, information on the presence and diversity of pests on asparagus planting is important to be assessed. This research aimed to study the diversity of insect pests on the land of asparagus plants in the Agroduta Cultivation Center Lembang, West Java. This study used survey methods where the collected data included the number and type of insects caught that the diversity index then were calculated. The samplings were using adhesive yellow trap and pitfall trap, carried out 6 times a week. The experiments were conducted on a land size of 12 x $6.5 \mathrm{~m}$ with an altitude of 1273 meters above sea level (masl). The results showed that the insects caught during the experiment were 7 insects, consisting of 17 families and 21 species, while the number of individual insects was 9.643. The index diversity of insects was categorized low because of the diversity index $<1$.

Keywords: Asparagus, Diversity, Insect Pest

\begin{abstract}
ABSTRAK
Sentra Budidaya Tanaman Agroduta Lembang Jawa Barat menghadapi kendala dalam peningkatan produksi asparagus yaitu adanya gangguan organisme pengganggu tanaman tanaman (OPT). Asparagus merupakan tanaman subtropis yang jarang dibudidayakan di Indonesia dan kemungkinan memiliki perbedaan jenis OPT. Oleh karena itu informasi keberadaan dan keragaman hama pada tanaman asparagus perlu diketahui. Penelitian ini bertujuan untuk mempelajari keragaman serangga hama pada lahan tanaman asparagus di sentra budidaya tanaman Agroduta Lembang, Jawa Barat. Penelitian ini mengguanakan metode survey. Data yang dikumpulkan meliputi jumlah dan jenis serangga yang tertangkap yang kemudian dihitung indeks keragamannya. Pengambilan sampel dilakukan dengan menggunakan perangkap kuning berperekat (yellow sticky trap) dan perangkap jebakan (pitfall) dilakukan selama 6 kali pegamatan dalam setiap minggunya. Percobaan dilakukan pada luas lahan berukuran 12 × 6,5 m dengan ketinggian 1273 meter di atas permukaan laut (mdpl). Hasil pengamatan menunjukkan bahwa serangga yang tertangkap selama percobaan sebanyak 7 ordo serangga, yang terdiri atas 17 famili dan 21 spesies, jumlah individidu serangga sebanyak 9.643. Indeks keragaman serangga dikatagorikan rendah karena indeks keragaman $<1$.
\end{abstract}

Kata Kunci: Asparagus, Keragaman, Serangga Hama 


\section{PENDAHULUAN}

Asparagus merupakan tanaman tahunan (perennial) dari family Liliaceae yang dimanfaatkan rebungnya. Dari genus asparagus hanya Asparagus officinalis yang dapat dikomsumsi sebagai sayuran, sementara spesies lain dari genus ini dimanfaatkan sebagai tanaman hias (Onggo, 2013). Permintaan yang banyak dan nilai ekonomi yang tinggi menjadikan sayuran ini tergolong sayuran eksotis di kalangan masyarakat dunia dan juga di Indonesia. Hal tersebut menjadikan banyak petani tertarik untuk ikut membudidayakan asparagus. Pertumbuhan tanaman asparagus di Indonesia lambat dikarenakan perbedaan antara iklim subtropis dan tropis dan tanaman ini tidak mengalami dormansi pada iklim tropis yang memengaruhi tingkat produktivitas rebung asparagus dan kualitasnya.

Rendahnya produksi asparagus disebabkan oleh beberapa faktor diantaranya yaitu adanya gangguan serangan serangga hama. Akibat serangan ini produktivitas hasil asparagus menurun karena banyak batang asparagus yang tidak memenuhi kriteria pasar. Namun demikian, tidak semua serangga bersifat merugikan karena ada juga serangga yang memiliki peran positif sebagai predator, parasitoid, atau musuh alami yang dapat dimanfaatkan sebagai pengendali hayati untuk tanaman budidaya (Christian \& Gotisberger, 2000).

Hama yang menyerang asparagus cukup bayak tergantung dari lokasi penanaman, tanaman yang tumbuh di sekitarnya, penggunaan naungan dan teknik budidaya yang dilakukan (Rizali dkk., 2002). Hama ulat grayak (Spodoptera litura) dan belalang (Valanga nigricornis) umumnya menyerang daun dan juga rebung yang baru tumbuh dan hama kutu kebul (Bemisia sp.) menyerang daun dan menghisap cairan yang ada pada tanaman (Onggo, 2013).

Tingkat keragaman jenis serangga memiliki peran yang penting bagi kestabilan di dalam ekosistem. Keanekaragaman jenis adalah sifat komunitas yang memperlihatkan tingkat keanekaragaman jenis organisme yang ada didalamnya. Untuk memperoleh keragaman jenis ini diperlukan kemampuan mengenal dan membedakan jenis hama (Putra, 1994). Keanekaragaman hayati serangga berpengaruh terhadap kuantitas dan kualitas produk pertanian yang dihasilkan, pada ekosistem alami umumnya telah terjadi kestabilan populasi antara hama dan musuh alami sehingga keberadaan serangga hama tidak lagi merugikan (Widiarta dkk., 2000). Tingkat keanekaragaman pertanaman tanaman memengaruhi timbulnya masalah hama, sistem pertanaman yang beranekaragam berpengaruh kepada populasi spesies hama (Oka, 1995).

Keberadaan serangga hama dalam suatu ekosistem pertanaman akan memengaruhi kegiatan budidaya karena secara langsung akan menurunkan kualitas dan kuantitas produk yang dihasilkan dan jika kegiatan pengendalian tidak dilakukan maka kegiatan budidaya akan mengalami kerugian. Kerugian yang akan dihadapi merupakan berbagai faktor yang berpengaruh terhadap pertumbuhan tanaman seperti tinggi rendahnya serangan hama, oleh karena itu pengendalian hama penting untuk dilakukan (Dadang dkk., 2007).

Dengan mempelajari struktur ekosistem seperti komposisi jenis-jenis tanaman, hama, musuh alami, dan kelompok biotik lainya, serta interaksi dinamis antar komponen biotik, dapat ditetapkan strategi pengelolaan yang mampu mempertahankan populasi hama pada suatu aras yang tidak merugikan (Pradhana dkk., 2014). Informasi mengenai keragaman serangga dan kelimpahannya pada budidaya asparagus hingga saat ini belum banyak diketahui. Oleh karena itu, mengetahui keragaman dan kelimpahannya pada tanaman asparagus perlu dilakukan agar pengelolaan dan pengendalian yang dilakukan pada asparagus dapat dilakukan dengan baik.

\section{BAHAN DAN METODE}

\section{Pemasangan Perangkap}

Eksplorasi keragaman serangga hama dilakukan dengan pemasangan perangkap kuning berperekat (yellow sticky trap) dan perangkap jebakan (pitfall) pada tanaman asparagus yang dibudidayakan di sentra budidaya tanaman Agroduta, Lembang, Jawa Barat. Lahan pengamatan berukuran 12 × 6,5 m dan pemasangan perangkap dilakukan dengan pola diagonal. Perangkap kuning berperekat dibentangkan ke dua sisinya lalu dilipat menjadi 2 sehingga menjadi persegi kembali kemudian bagian tengah diikat dengan tali yang mengikat di antara tanaman kemudian perangkap digantungkan. Perangkap kuning berperekat didiamkan selama seminggu di areal percobaan.

Perangkap jebakan (pitfall) digunakan untuk menagkap serangga yang hidup di atas permukaan tanah. Pada masing-masing titik sampel 
ditanam wadah air pelastik berukuran kecil wadah plastik di isi larutan air yang diberikan diterjen untuk membuat permukaan wadah pelastik dan mecegah serangga kabur. Tanah yang sudah digali dimasukkan perangkap pitfall dan dibuat rata dengan tanah agar serangga mudah terjebak saat melewati perangkap tersebut. Pengambilan sampel dilakukan seminggu sekali sejak bulan Februari 2016 sampai dengan April 2016.

\section{Preservasi dan Identifikasi Serangga}

Serangga yang tertangkap pada kedua perangkap diambil dan dihitung jumlahnya serta dipisahkan jenisnya. Pada perangkap kuning berperekat pengoleksian serangga dilakukan dengan membasahkan perangkap dengan larutan $\mathrm{N}$ Hexan dan dibantu dengan kuas. Serangga yang terkumpul dimasukkan ke dalam tabung kecil berpenutup menggunakan pinset secara hati-hati. Identifikasi dilakukan dengan cara mengamati morfologi dengan menggunakan mikroskop dan untuk menemukan taksonomi serangga menggunakan kunci identifikasi serangga (Borror et al., 1996), serta buku kunci identifikasi The Pest of Crops in Indonesia (Kalshoven, 1981), dan menggunakan software Deltainkey.

\section{Analisis Data}

Data yang dikumpulkan meliputi jumlah dan jenis serangga yang terperangkap dan diidentifikasi. Kemudian data yang diperoleh dianalisis dengan menghitung indeks keragaman jenis (Shannon weiner) dan kelimpahannya (Tabel 1). Serangga yang terdapat dalam botol koleksi dihitung jumlah tiap individu serangga menggunakan rumus nilai Kelimpahan Relatif (KR) dihitung dengan rumus (Magurran, 2004) dan Perhitungan indeks keragaman jenis serangga Shannon Weiner(Krebs, 1978):

$$
\begin{aligned}
& K R=\frac{n}{N} \times 100 \% \\
& \mathrm{KR} \text { = Kelimpahan relative } \\
& \mathrm{N} \text { = Jumlah individu serangga } \\
& \mathrm{n} \quad=\text { Jumlah total serangga } \\
& H^{\prime}=-\sum P i(L n P i) \\
& \mathrm{Pi}=\sum \mathrm{ni} / \mathrm{N} \\
& \mathrm{H}=\text { Indeks Keragaman Shannon-Wiener } \\
& \mathrm{Pi}=\text { Jumlah individu suatu spesies/jumlah total } \\
& \text { seluruh spesies } \\
& \mathrm{ni}=\text { Jumlah individu spesies ke-i } \\
& \mathrm{N} \text { = Jumlah total individu }
\end{aligned}
$$

Tabel 1. Klasifikasi Nilai Indeks Keragaman Shannon-Wiener (H').

\begin{tabular}{cl}
\hline Nilai Indeks Shannon & \multicolumn{1}{c}{ Kategori } \\
\hline$<1$ & $\begin{array}{l}\text { Keanekaragaman rendah, penyebaran jumlah individu tiap spesies rendah dan } \\
\text { kestabilan komunitas rendah. } \\
\text { Keanekaragaman sedang, penyebaran jumlah individu tiap spesies sedang dan } \\
\text { kestabilan komunitas sedang. } \\
\text { Keanekaragaman tinggi, penyebaran jumlah individu tiap spesies tinggi dan } \\
\text { kestabilan komunitas tinggi. }\end{array}$ \\
\hline
\end{tabular}

Sumber: Krebs (1978)

\section{HASIL DAN PEMBAHASAN}

Hasil pengamatan yang telah dilakukan didapatkan jumlah serangga yang tertangkap pada perangkap kuning keseluruhan berjumlah 9.504 individu. Hal ini mendominasi hasil tangkapan dibandingkan dengan perangkap pitfall yang hanya menangkap 139 individu serangga. Jenis serangga yang terperangkap pada perangkap kuning terdiri dari berbagai macam famili/spesies (Tabel 2). Perangkap kuning lebih efektif menangkap serangga dari ordo Homoptera dan Diptera, masing-masing berjumlah 8782 dan 677 individu. Sedangkan perangkap pitfall banyak menangkap golongan serangga dari Hymenoptera. Komposisi peranan serangga yang ditemukan pada lahan asparagus tersebut terdiri dari 4 golongan yaitu serangga herbivor, musuh alami (predator dan parasitoid), saprovora, dan serangga lainnya. Serangga herbivor mendominasi dibandingkan dengan serangga lain dengan persentase mencapai $97,81 \%$ dari total semua serangga yang tertangkap (Tabel 2).

Hasil pengamatan didapatkan jumlah serangga yang tertangkap selalu berfluktuasi, jumlah 
serangga hama dan musuh alami maupun serangga lainnya di lahan tanaman asparagus terjadi setiap minggunya. Hasil pengamatan dari minggu pertama sampai pengamatan minggu ke enam di dapatkan tangkapan terendah yaitu pada pengamatan minggu ketiga dengan jumlah tangkapan sebanyak 1483 individu serangga dan tangkapan tertinggi terdapat pada pengamatan minggu keenam dengan jumlah tangkapan sebanyak 1782 individu serangga. Berdasarkan hasil penelitian yang dilakukan selama beberapa minggu pengamatan didapatkan hasil perhitungan indeks keragaman serangga pada setiap waktu pengamatan selalu berubah-ubah (Tabel 3).

Tabel 2. Jumlah serangga yang ditemukan pada tiap perangkap di lahan asparagus.

\begin{tabular}{|c|c|c|c|c|c|}
\hline \multicolumn{2}{|c|}{ Serangga } & \multicolumn{2}{|c|}{ Perangkap } & \multirow{2}{*}{$\begin{array}{c}\text { Total } \\
\text { individu }\end{array}$} & \multirow{2}{*}{ Kelimpahan \% } \\
\hline Ordo & Famili/spesies & Kuning & Pitfall & & \\
\hline \multirow{8}{*}{ Diptera } & Takinide sp. & 2 & & 2 & $0.02 \%$ \\
\hline & Bactrocera papaya & 463 & & 463 & $4.80 \%$ \\
\hline & Bactrocera umbrosa & 27 & & 27 & $0.28 \%$ \\
\hline & Ophiomyia simplex Loew & 136 & & 136 & $1.41 \%$ \\
\hline & Muscidae sp. (a) & 4 & & 4 & $0.04 \%$ \\
\hline & Muscidae sp. (b) & 20 & & 20 & $0.20 \%$ \\
\hline & Conopidae sp. & 10 & & 10 & $0.10 \%$ \\
\hline & Calliphoridae sp. & 15 & & 15 & $0.15 \%$ \\
\hline Lepidoptera & Hesperiidae sp. & 8 & & 8 & $0.08 \%$ \\
\hline \multirow{4}{*}{ Hymenoptera } & Amegilla calceifera & 6 & & 6 & $0.06 \%$ \\
\hline & Dolichoderus bituberculatus & & 10 & 10 & $0.10 \%$ \\
\hline & Formicidae sp. & & 24 & 24 & $0.24 \%$ \\
\hline & Oecophylla smaragdina & & 86 & 86 & $0.89 \%$ \\
\hline \multirow{4}{*}{ Coleoptera } & Carabidae sp. & 1 & & 1 & $0.01 \%$ \\
\hline & Epilachna varivestis & 14 & & 14 & $0.14 \%$ \\
\hline & Menochilus sexmaculatus & 16 & & 16 & $0.16 \%$ \\
\hline & Tenebrionidae sp. & & 4 & 4 & $0.04 \%$ \\
\hline \multirow{2}{*}{ Homoptera } & Empoasca sp. & 75 & & 75 & $0.77 \%$ \\
\hline & Bemisia sp. & 8707 & & 8707 & $90.29 \%$ \\
\hline Dermaptera & Forficulidae sp. & & 4 & 4 & $0.04 \%$ \\
\hline \multirow{3}{*}{ Araneae } & Lycosidae sp. (a) & & 6 & 6 & $0.06 \%$ \\
\hline & Lycosidae sp. (b) & & 5 & 5 & $0.05 \%$ \\
\hline & Total & 9504 & 139 & 9643 & \\
\hline
\end{tabular}

Dari hasil pengamatan dan penggunaan perangkap serangga, diketahui bahwa serangga hama yang paling banyak ditemukan di lahan tanaman asparagus di sentra budidaya tanaman Agroduta Lembang Jawa Barat yaitu adalah serangga dari famili Aleyrodidae yaitu (Bemisia sp.) dengan kelimpahan 90,29\% dari total keseluruhan serangga yang berhasil didapatkan. Hal ini sesuai dengan yang disebutkan Onggo (2013) bahwa hama kutu kebul (Bemisia sp.) merupakan salah satu hama yang menyerang daun dan menghisap cairan yang ada pada tanaman asparagus.
Selain menyerang tanaman asparagus kutu kebul menyerang banyak tanaman karena bersifat polifag. Beberapa strain Bemisia sp. menghasilkan lebih banyak embun jelaga, dan kutu betina memiliki kapasitas reproduksi lebih tinggi, sehingga sulit dikendalikan dengan insektisida kimia (Bennett et al., 2012). Inang utama kutu kebul terdiri dari famili Compositae, Cucurbitaceae, Cruciferae, dan Solanaceae (Kalshoven, 1981). Dimana sesuai dengan keadaan lokasi pengamatan yang juga terdapat beberapa tanaman dari famili Solanaceae. 
Tabel 3. Peranan fungsional serangga dan persentasenya.

\begin{tabular}{|c|c|c|c|c|}
\hline Peranan & Ordo & Famili & Spesies & Persentase (\%) \\
\hline \multirow{7}{*}{ Herbivora } & \multirow{3}{*}{ Diptera } & Agromyzidae & Ophiomyia simplex $\mathrm{L}$. & \multirow{7}{*}{97,81} \\
\hline & & \multirow{2}{*}{ Tephritidae } & Bactrocera papaya & \\
\hline & & & Bactrocera umbrosa & \\
\hline & \multirow{2}{*}{ Homoptera } & Cicadellidae & Empoasca sp. & \\
\hline & & Aleyrodidae & Bemisia sp. & \\
\hline & Lepidoptera & Hesperiidae & Hesperiidae sp. & \\
\hline & Coleoptera & Coccinellidae & Epilachna varivestis & \\
\hline \multirow{2}{*}{ Parasitoid } & \multirow{2}{*}{ Diptera } & Takanidae & Takinide sp. & \multirow{2}{*}{0,12} \\
\hline & & Conopidae & Conopidae sp. & \\
\hline \multirow{8}{*}{ Predator } & Dermaptera & Forficulidae & Forficulidae sp. & \multirow{8}{*}{1,56} \\
\hline & Coleoptera & Carabidae & Carabidae sp. & \\
\hline & \multirow{3}{*}{ Araneae } & Lycosidae & Lycosidae sp. (a) & \\
\hline & & \multirow[t]{2}{*}{ Lycosidae } & Lycosidae sp. (b) & \\
\hline & & & Dolichoderus bituberculatus & \\
\hline & \multirow[t]{2}{*}{ Hymenoptera } & \multirow[t]{2}{*}{ Formicidae } & Oecophylla smaragdina & \\
\hline & & & Formicidae sp. & \\
\hline & Coleoptera & Coccinellidae & Menochilus sexmaculatus & \\
\hline \multirow{4}{*}{ Saprovora } & Diptera & Calliphoridae & Calliphoridae sp. & \multirow{4}{*}{0,45} \\
\hline & Diptera & Muscidae & Muscidae sp. (a) & \\
\hline & & & Muscidae sp. (b) & \\
\hline & Coleoptera & Tenebrionidae & Tenebrionidae $S p$ & \\
\hline Serangga lain & Hymenoptera & Apidae & Amegilla calceifera & 0,06 \\
\hline
\end{tabular}

Serangan hama kutu kebul menyebabkan kerusakan langsung dan tidak langsung. Kerusakan yang ditimbulkan oleh kutu kebul sangat kompleks meliputi kerusakan karena proses makan kutu kebul baik nimfa dan serangga dewasa, kontaminasi embun madu yang mendorong perkembangan cendawan, penyebaran penyakit virus, dan gangguan proses fisiologis tanaman (McAuslane et al., 1995). Kerusakan langsung terlihat dari adanya bercak nekrotik pada daun akibat rusaknya sel-sel dan jaringan daun dan klorosis karena cairan daun dihisap kutu kebul (Mau \& Keesing, 2007). Kerusakan tidak langsung berupa timbulnya cendawan embun jelaga yang berkembang pada kotoran kutu kebul yang dapat menyebabkan proses fotosintesis tidak berlangsung normal.

Serangga yang paling sedikit ditemukan adalah kumbang dari famili Carabidae yang merupakan preadator. Merupakan kumbang tanah yang biasa ditemukan di bawah-bawah batu atau dedaunan dan pada siang hari merekat tidak aktif dan aktif mencari makan pada malam hari serta memiliki ketertarikan pada cahaya (Borror et al., 1996).

Berdasarkan Tabel 4 diketahui bahwa indeks keragaman serangga pada perangkap yang di aplikasian setiap minggunya mengalami perubahan dan indeks keragaman tiap pengamatannya kurang dari 1 sehingga termasuk kategori keragaman rendah. Dalam pengamatan dilapangan nilai indeks keragaman $\left(\mathrm{H}^{\prime}\right)$ dipengaruhi oleh faktor lingkungan, jika nilai keragaman $<1$ maka kondisi dilingkungan tidak setabil. Dari hasil pengamatan setiap minggunya terlihat berubah-ubah atau fluktuatif. Hal ini disebabkan oleh pengaruh faktor lingkungan di lapangan. Hal tersebut sesuai dengan yang dikatakan Odum (1993) sebagaimana diketahui bahwa indeks keragaman serangga pada ekosistem yang secara fisik terkendali cenderung rendah, dan tinggi pada ekosistem alamiah. Berbeda pada ekosistem alami peluang nilai indeks keragamannya dapat >2 (Michael, 1984)

Selain itu faktor rendahnya indeks keragaman pada lahan asparagus di duga karena bahwa lahan tanaman asparagus merupakan sebuah areal tanaman budidaya tanaman hortikultura yang luas dan berorientasi bisnis. Praktek budidaya tanaman memungkinkan menggunakan pengendalian serangga dengan menggunakan pestisida sehingga mengakibatkan pencemaran lingkungan. Sebagaimana telah diketahui bahwa pencemaran lingkungan pertanian oleh pestisida 
sintetis telah menimbulkan beberapa akibat diantaranya yaitu resistensi serangga hama, timbulnya hama sekunder, adanya residu pada hasil pertanian yang dikonsumsi, dan membunuh musuhmusuh alami hama yang merupakan komponen biotik penting dalam pengendalian serangga hama (Natawigena, 1989). Perkembangan atau kelimpahan suatu serangga dipengaruhi oleh faktor cuaca, ketersediaan makanan dan kepadatan populasinya. Pada suatu ekosistem, serangga memiliki kemampuan untuk beradaptasi dengan lingkungannya dan serangga dapat juga menghindari keadaan ekstrim suatu lingkungan.

Tabel 4. Keragaman serangga pada lahan tanaman asparagus.

\begin{tabular}{cccccc}
\hline Pengamatan & $\sum n$ & $\sum p i$ & $\sum \ln p i$ & $\mathrm{H}^{\prime}$ & Keragaman \\
\hline 1 & 1499 & 1 & -122.251 & 0.531967182 & Rendah \\
2 & 1683 & 1 & -99.1049 & 0.458854704 & Rendah \\
3 & 1483 & 1 & -105.561 & 0.580467675 & Rendah \\
4 & 1625 & 1 & -99.0374 & 0.470111032 & Rendah \\
5 & 1571 & 1 & -75.4485 & 0.467527032 & Rendah \\
6 & 1782 & 1 & -80.1028 & 0.411029488 & Rendah \\
\hline
\end{tabular}

Keterangan:

H'= Indeks Keragaman

$\mathrm{Pi}=$ Perbandingan Jumlah individu serangga ke-I dengan keseluruhan serangga

$\mathrm{Ni}=$ Jumlah Serangga ke-i

Keberadaan arthropoda musuh alami harus diperhatikan dan diselamatkan, karena arthropoda musuh alami dapat membantu dalam pengendalian serangga hama yang bersifat ramah lingkungan. Hasil kajian mengenai keragaman dan kelimpahan serangga pada tanaman asparagus di sentra budidaya tanaman Agroduta Lembang Jawa Barat, merupakan salah satu kegiatan penelitian yang dapat membantu pemahaman tentang konsep-konsep ekologi serangga khususnya tentang konsep keragaman hama pada tanaman asparagus.

\section{SIMPULAN}

Bedasarkan hasil survei yang dilakukan, maka dapat diambil kesimpulan Indeks keragaman $\left(H^{\prime}\right)$ serangga hama pada tanaman asparagus di sentra budidaya tanaman Agroduta Lembang Jawa Barat, berdasarkan pengamatan didapatkan indeks keragaman dikategorikan rendah karena indeks keragaman <1. Hal ini menunjukkan kondisi lingkungan yang kurang stabil dan munculnya dominasi serangga hama. Persentase serangga hama $(97,81 \%)$, predator $(1,56 \%)$ parasitoid $(0,12 \%)$, saprovora $(0,45 \%)$ dan serangga lainya $(0,06 \%)$.

\section{DAFTAR PUSTAKA}

Bennett, JC, A Diqqle, F Evan, and M Renton. 2012. Assesing eradication strategies for rain splashed and wind dispersed crop diseases. Pest Management Science. 69(8):966-963.

Borror DJ, CA Triplehorn, and NF Jhonson. 1996. Pengenalan Pelajaran Serangga. S Partosoetiono (Penerjemah). Edisi Keenam. Gadjah Mada University Press, Yogyakarta.

Christian, W, and G Gottsberger. 2000. Diversity preys in crop pollination. Crop Science. 40(5):1209-1222.

Dadang, G Suastika, dan RS Dewi. 2007. Hama dan Penyakit Tanaman Jarak Pagar (Jatropha curcas). Surfactant and Bioenergy Research Center, Bogor.

Kalshoven, LGE. 1981. The Pest of Crops in Indonesia. PT. Ichtiar Baru van Hoeve, Jakarta.

Krebs, CJ. 1978. Ecology: The Experimental Analysis of Distribution and Abudance. Third Edition. Harper and Row Publisher, New York.

Magurran, AE. 2004. Measuring Biological Diversity. Blackwell Science, USA.

Mau, RFL, and JLM Kessing. 2007. Sweetpotato whitefly (Bemisia tabaci). Tersedia online pada www.extento. hawai.edu. Diakses pada 20 Mei 2016.

McAuslane, HEJ, DA Knauft, and FA Johnson. 1995. Evaluation of peanut breeding lines for resistance to silverleaf whitefly 
(Homoptera: Aleyrodidae). Florida Entomologist Online. 78(1):76-82.

Michael, P. 1984. Ecological Method for Field and Laboratory Investigation. Tata McGrawwHill-Publishing Company Limited, New Delhi.

Natawigena, H. 1989. Pestisida dan Kegunaannya. CV. Armico, Bandung.

Odum, EP. 1993. Dasar-dasar Ekologi. Gadjah Mada University Press, Yogyakarta.

Onggo, TM. 2013. Budidaya Tanaman Asparagus Di Daerah Tropis. Unpad Press, Bandung.

Oka, IN. 1995. Pengendalian Hama Terpadu dan Implementasinya. Gadjah Mada University Press, Yogyakarta.

Pradhana, RAI, G Mudjiono, S Karindah. 2014. Keanekaragaman serangga dan laba-laba pada pertanaman padi organik dan konvensional. Jurnal HPT. 2(2) :58-66.

Putra, NS. 1994. Serangga di Sekitar Kita. Kanisius, Yogyakarta.

Rizali, A, D Bukhori, dan H Triwidodo. 2002. Keanekaragaman serangga pada lahan persawahan-tepaian hutan indikator untuk kesehatan lingkungan. Jurnal Penelitian. 9(2):41-48.

Widiarta, IN, T Suryana, dan D Kusdiaman. 2000. Jenis anggota komunitas pada berbagai habitat lahan sawah bera dan usaha konservasi musuh alami pada padi tanaman serempak. Hlm. 185-182 dalam Prosiding Simposium Keanekaragaman Hayati Arthropoda pada Sistem Produksi Pertanian (E Sunaryo, Ed). Perhimpunan Entomologi Indonesia. Cipayung 16-18 Oktober 2000. 